\title{
Economic Analysis of Waste Heat Utilization for Coal-fired Power Units
}

\author{
Wang Kai , Lu Kun, Wang Shuai \\ Shandong Branch, Huadian Electric Power Research Institute Co., Ltd, Jinan, China
}

\begin{abstract}
Strict energy conservation policies require power plants to minimize energy consumption as much as possible. Low pressure economizer is an effective method to recycle waste heat from boiler exhaust gas. In this paper, the economic analysis model of coal-fired power plant is established by means of equivalent enthalpy drop method, and the waste heat utilization effect on thermal systems is investigated, including boiler efficiency, steam turbine power output, condensate pump, induced draft fan, electro static precipitator and desulfurization system. Then the economic effect on a $1000 \mathrm{MW}$ ultra super critical unit in Shandong Province is calculated. The results show that waste heat utilization could comprehensively reduce standard coal consumption rate by $1.89 \mathrm{~g} /(\mathrm{kW} \cdot \mathrm{h})$, and the unit could save about 10.8 thousand tons standard coal and 1.29 billion dollars every year. Besides, the energy saving effect is more significant for lower load condition.
\end{abstract}

\section{Introduction}

At present, more intense emission requirements are raised for coal fired power plants because of the improvement of energy conservation and emission reduction policies. According to statistics [1,2], the boiler exhaust loss accounts for the largest proportion of boiler heat loss, and the designing smoke exhaust temperature ranges from $120{ }^{\circ} \mathrm{C}$ to $140^{\circ} \mathrm{C}$ for most power plants.

However, the actual smoke exhaust temperature is generally higher than the design data. Take the flue pipe corrosion out of consideration, if the boiler exhaust temperature could be reduced to $70^{\circ} \mathrm{C} \sim 90^{\circ} \mathrm{C}$, then this part of waste heat could be used in steam turbine regenerative system [3].

Therefore, the power generation efficiency will be increased by 2 to 4 percent, and the standard coal consumption will reduce by 2 to $4 \mathrm{~g} /(\mathrm{kW} \cdot \mathrm{h})$ [4 6]. The thermal power generation capacity is about 4.29 trillion $\mathrm{kW} \cdot \mathrm{h}$ in 2016 in China, if exhaust waste heat is applied to all the national thermal power plants, the annual coal consumptions could be saved about 8.6 to 17 million tons [7].

The thermal economic evaluation for low pressure economizer should consider not only the waste heat recovery amount, but also the work capacity of squeezing out steam after being returned to the turbine [8]. Two methods are currently being used to evaluate the energy saving effect for low pressure economizer.

One is adopting the heat balance diagram, namely executing two tests for steam turbine thermal performance with and without the economizer runtime respectively [9], in order to get the two tests difference of power supply coal consumption rate.
The other one is using the equivalent enthalpy drop method to calculate the energy saving effect by means of steam turbine thermal performance test [10].

As to the research of waste energy recovery utilization, many scholars analyzed its energy saving effect by means of equivalent enthalpy drop method and thermal balance method. Huang analyzed the waste heat utilization effect of flue gas by equivalent enthalpy drop method for various utilization schematic systems [11].

Some studies show that exhaust waste heat utilization can increase the power output of the steam turbine, and the energy saving effect could be optimized by adjusting the low pressure economizer arrangement and the heat transfer parameters [12 15].

However, most studies at present focus mainly on the optimal design of the low pressure economizer, and on the local benefits or influence of waste heat recovery, few has investigated the overall effect of waste heat utilization on the unit system.

Therefore, the comprehensive heat recovery effect on the entire system of a 1000MW ultra super critical coalfired unit was analyzed in this paper, including boiler efficiency, steam turbine power output, draft fan, condensation pumps, dust collector and desulfurization system. Besides, the load effect on energy saving performance and thermal economy is discussed.

\section{Calculation model}

A 1000MW ultra super critical coal-fired unit in Shandong Province was investigated, which include an ultra-super critical once-through boiler with the design coal is composed of : Ash-8.8\%, Carbon-56.3\%, Hydrgen-3.8\%, Sulphur- $0.2 \%$, Nitrogen-0.8\%, Oxgen- 
$12.1 \%$, Moisture-18.0\%. The low calorific value of design coal is $21 \mathrm{MJ} / \mathrm{kg}$.

In addition, the steam turbine belongs to the condensing type with the model type N1000-26.3/600/600, and eight stage heat extraction is adopted to heat condensation water.

The low temperature electrostatic dust collection technology is used on this unit, and the low-pressure economizer is used to recycle the exhaust waste energy and heat condensation water.

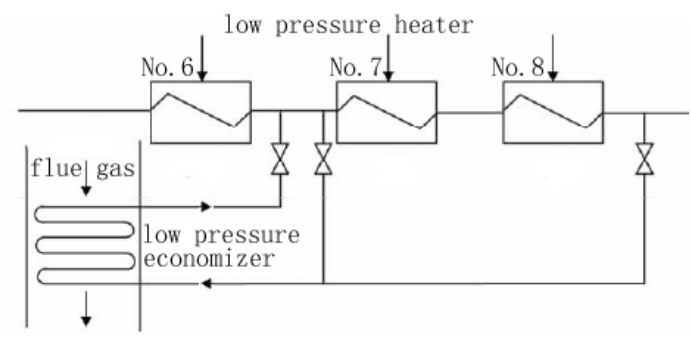

Fig. 1. Schematic diagram of low pressure economizer arrangement.

The schematic diagram is shown in Fig. 1, which is as follows. Low-pressure economizer inlet water is from No.7 low pressure heater outlet and shaft seal water valve export. After that, it enters into economizer module, and exchange heat with flue gas. Then it flows out of the module and returns into the No.6 low pressure heater inlet.

\section{Waste heat utilization impacts on thermal systems}

\subsection{Effect on boiler efficiency}

Boiler thermal efficiency is determined by heat balance and thermodynamic calculation of low pressure economizer. The detailed calculation process is shown in Fig. 2, and the heat exchange $Q_{\mathrm{j}}$ is calculated as the initial heat transfer in the next calculation.

Besides, the exhaust flue gas temperature $t_{\mathrm{j}}$, outlet water temperature $t_{\mathrm{wj}}$, average heat transfer temperature difference $\Delta t_{\mathrm{j}}$ and economizer heat transfer $Q_{\mathrm{j}}$ are calculated in turns.

If the criterion $\left|Q_{\mathrm{j}}-Q_{\mathrm{j}-1}\right| / Q_{\mathrm{j}}<\varepsilon$ (calculation error) is not met, then perform the next iterative calculation. By modifying the method of iteration, the efficiency of calculation can be improved.

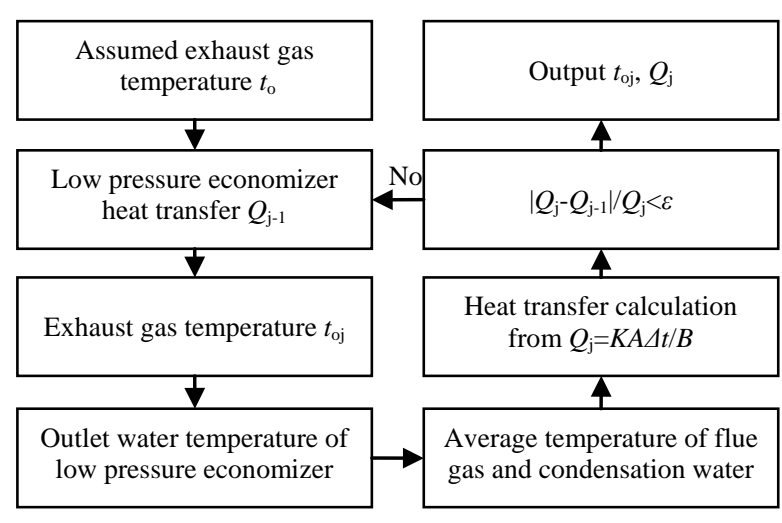

Fig. 2. Calculation process for heat exchange.

In turbine heat acceptance conditions, the calculation parameters are as follows: exhaust gas inlet temperature$130^{\circ} \mathrm{C}$, condensation water inlet temperature $-70.2^{\circ} \mathrm{C}$, gas flow aera-338 $\mathrm{m}^{2}$, heat transfer aera-77500 $\mathrm{m}^{2}$.

After iteration and verifying calculation, the thermaldynamic performance parameters of low pressure economizer are shown in Table1.

Table 1. Thermal Performance of Low Pressure Economizer.

\begin{tabular}{ll}
\hline Items & Data \\
\hline Exhaust gas outlet temperature $/{ }^{\circ} \mathrm{C}$ & 86.5 \\
Condensation water outlet temperature $/{ }^{\circ} \mathrm{C}$ & 109.8 \\
Heat transfer coefficient $/ \mathrm{W} /\left(\mathrm{m}^{2} \cdot \mathrm{K}\right)$ & 36.2 \\
Average heat transfer temperature difference $/{ }^{\circ} \mathrm{C}$ & 18.2 \\
Heat exchange amount & $51153 \mathrm{Kw}$ \\
\hline
\end{tabular}

It can be seen from Table 1 that the low pressure economizer could decrease boiler exhaust temperature from $130{ }^{\circ} \mathrm{C}$ to $86.5{ }^{\circ} \mathrm{C}$, and the exhaust heat loss decreases from $6.9 \%$ to $4.5 \%$. Therefore, boiler thermal efficiency rises from $93.5 \%$ to $95.8 \%$.

\subsection{Effect on steam turbine power output}

The equivalent enthalpy drop method was used to analyze the influence of the waste heat utilization on steam turbine. During the heat recovery process, the condensation water could be heated, which can reduce the turbine steam extraction amount and generate extra power.

Based on the equivalent enthalpy drop method, the equivalent enthalpy drop increment $\Delta H$ caused by the exhaust heat utilization could be calculated, and the heat recovery performance could be evaluated.

If the low pressure economizer is in series arrangement as shown in Fig. 3, the equivalent enthalpy drop increment $\Delta H$ is as follows in (1).

$$
\Delta H=Q_{\mathrm{d}} \cdot \eta_{\mathrm{j}} / D_{0}
$$

Where $D_{0}$ is superheated steam flow rate, $\mathrm{kg}$. $Q_{\mathrm{d}}$ is waste heat amount, $\mathrm{kJ} . H_{\mathrm{j}}$ is extraction efficiency of the reheating heater corresponding to the waste heat, $\%$. 


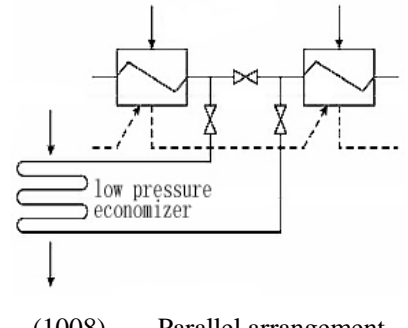

(1008) Parallel arrangement

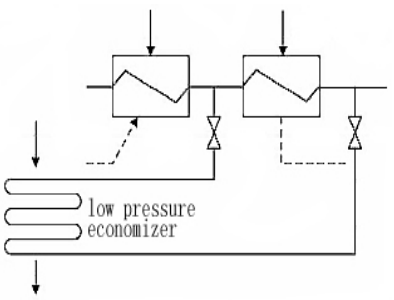

(b)Series arrangement

Fig. 3. Typical arrangement patterns for low pressure economizer.

If the low pressure economizer is in parallel arrangement with the No. $\mathrm{n}$ to $(\mathrm{m}-1)$ low pressure heater, the equivalent enthalpy drop increment $\Delta H$, heat rate decrement $\Delta q$ and standard coal consumption rate decrement $\Delta b_{\text {cp }}$ could be calculated as follows.

$$
\begin{aligned}
& \Delta H=\beta\left[\left(h_{\mathrm{d}}-h_{\mathrm{w}(\mathrm{m}-1)}\right) \cdot \eta_{\mathrm{m}}+\sum_{\mathrm{j}=\mathrm{n}}^{\mathrm{m}-1}\left(l_{\mathrm{j}} \cdot \eta_{\mathrm{j}}\right)\right] \\
& \Delta q=q \cdot \Delta H /(H+\Delta H) \\
& \Delta b_{\mathrm{cp}}=1000 \cdot \Delta q /\left(\eta_{\mathrm{b}} \cdot \eta_{\mathrm{p}} \cdot 29270\right)
\end{aligned}
$$

Where $\beta$ is discharge coefficient of inlet condensation water for low pressure economizer. $H_{\mathrm{d}}$ ” is outlet water enthalpy, kJ/kg. $h_{\mathrm{w}(\mathrm{m}-1)}$ is outlet water enthalpy of No. (m-1) low pressure heater, $\mathrm{kJ} / \mathrm{kg} . \eta_{\mathrm{m}}$ is extraction efficiency of No. $\mathrm{m}$ heater, \%. $I_{\mathrm{i}}$ is enthalpy increase of parallel heater condensation water. $Q$ is the original heat rate of steam turbine, $\mathrm{kJ} /(\mathrm{kW} \cdot \mathrm{h}) . H$ is the net equivalent enthalpy decrease, $\mathrm{kJ} /(\mathrm{kW} \cdot \mathrm{h}) . \quad \eta_{\mathrm{p}}$ and $\eta_{\mathrm{b}}$ are pipe efficiency and boiler efficiency respectively.

Because the energy saving effect of the waste heat is achieved by squeezing out steam from the steam turbine, the boiler efficiency is defined as the air preheater outlet gas temperature.

Table 2 shows the extraction parameters of a 1000 MW steam turbine in heat acceptance condition. By means of equivalent enthalpy method, the waste heat utilization effect on steam turbine is shown in Table 3 .

It can be seen that power generation increases 11.46 $\mathrm{kJ}$ per kilogram steam, and the turbine power output increases 8.4 MW with $2.32 \mathrm{~g} /(\mathrm{kW} \cdot \mathrm{h})$ decrease for standard coal consumption rate.

Table 2. Thermal Parameters of All Heaters in Turbine Heat Acceptance Conditions.

\begin{tabular}{ccccc}
\hline $\begin{array}{c}\text { Heater } \\
\text { Number }\end{array}$ & $\begin{array}{c}\text { Steam } \\
\text { Extraction } \\
\text { temperature }\end{array}$ & $\begin{array}{c}\text { Steam } \\
\text { Extraction } \\
\text { Enthalpy }\end{array}$ & $\begin{array}{c}\text { Extraction } \\
\text { Flow Rate } \\
/ \mathrm{kg}^{-1} \mathrm{~s}^{-1}\end{array}$ & $\begin{array}{c}\text { Outlet } \\
\text { Water } \\
\text { Temperature }\end{array}$ \\
\hline
\end{tabular}

\begin{tabular}{|c|c|c|}
\hline Items & $\begin{array}{c}\text { Before } \\
\text { Modification }\end{array}$ & $\begin{array}{c}\text { After } \\
\text { Modification }\end{array}$ \\
\hline Exhaust gas temperature $/{ }^{\circ} \mathrm{C}$ & 130.0 & 86.5 \\
\hline $\begin{array}{l}\text { Squeezing steam work of } \\
\text { No.8 heater } \Delta H_{8} / \mathrm{kJ} \mathrm{kg}^{-1}\end{array}$ & 1 & 0.82 \\
\hline $\begin{array}{l}\text { Squeezing steam work of } \\
\text { No.7 heater } \Delta H_{7} / \mathrm{kJ} \cdot \mathrm{kg}^{-1}\end{array}$ & 1 & 1.48 \\
\hline $\begin{array}{l}\text { Squeezing steam work of } \\
\text { No. } 6 \text { heater } \Delta H_{6} / \mathrm{kJ} \cdot \mathrm{kg}^{-1}\end{array}$ & 1 & 9.15 \\
\hline $\begin{array}{l}\text { Increment of equivalent enthalpy } \\
\text { drop } \Delta H / \mathrm{kJ} \cdot \mathrm{kg}^{-1}\end{array}$ & 1 & 11.43 \\
\hline $\begin{array}{l}\text { Steam equivalent enthalpy } \\
\text { drop } H / \mathrm{kJ} \cdot \mathrm{kg}^{-1}\end{array}$ & 1357.62 & 1369.08 \\
\hline $\begin{array}{l}\text { Heat consumption rate } q_{0} / \\
\mathrm{kJ} \cdot(\mathrm{kW} \cdot \mathrm{h})^{-1}\end{array}$ & 7346 & 7283 \\
\hline $\begin{array}{l}\text { Decrement of heat consumption rate } \\
\Delta q_{0} / \mathrm{kJ} \cdot(\mathrm{kW} \cdot \mathrm{h})^{-1}\end{array}$ & 1 & 63 \\
\hline $\begin{array}{l}\text { Steam consumption rate } d_{0} / \\
\mathrm{kg} \cdot(\mathrm{kW} \cdot \mathrm{h})^{-1}\end{array}$ & 2.708 & 2.689 \\
\hline $\begin{array}{l}\text { Generation standard coal } \\
\text { consumption } \\
\text { rate } b_{\mathrm{cp}} / \mathrm{g} \cdot(\mathrm{kW} \cdot \mathrm{h})^{-1}\end{array}$ & 277.51 & 275.19 \\
\hline $\begin{array}{l}\text { Standard coal consumption } \\
\text { savings } \Delta b_{\mathrm{cp}} / \mathrm{g} \cdot(\mathrm{kW} \cdot \mathrm{h})^{-1}\end{array}$ & 1 & 2.32 \\
\hline Power generation $P_{\mathrm{e}} / \mathrm{MW}$ & 1000 & 1008.4 \\
\hline
\end{tabular}

\begin{tabular}{ccccc}
\hline \multicolumn{5}{c}{$/{ }^{\circ} \mathbf{C} \mathbf{J} \cdot \mathbf{k g}^{-1}$} \\
\hline 1 & 395.4 & 3136.4 & 39.98 & 289.9 \\
2 & 353.2 & 3064.2 & 75.79 & 268.7 \\
3 & 481.9 & 3420.9 & 31.28 & 219.8 \\
Deaerator & 382.5 & 3223.7 & 70.66 & 189.6 \\
5 & 289.4 & 3040.5 & 30.74 & 153.1 \\
6 & 191.9 & 2851.6 & 35.40 & 121.8 \\
7 & 99.4 & 2629.4 & 21.17 & 83.0 \\
8 & 94.3 & 2495.3 & 20.95 & 60.9 \\
\hline
\end{tabular}

Table 3. Waste Heat Utilization Effect on Steam Turbine.

\subsection{Effect on condensate pump}

If the low pressure economizer is arranged in series, a resistance is added to the original system, and it is necessary to increase condensate pump output or use booster pump to overcome the resistance.

On the contrary, the power consumption will not increase if the economizer is arranged in parallel, because the condensation water pressure is sufficient to overcome the economizer resistance.

As to the series arrangement, the power consumption increment of condensate pump $\Delta P_{\mathrm{p}}$ is equal to $q_{\mathrm{w}} \cdot \Delta P_{\mathrm{w}} /\left(3600 \cdot \eta_{\mathrm{p}}\right)$. Where $q_{\mathrm{w}}$ is economizer water flow rate, $\mathrm{m}^{3} / \mathrm{h}$. $\Delta P_{\mathrm{w}}$ is economizer water resistance, $\mathrm{Pa} . \eta_{\mathrm{p}}$ is condensate pump efficiency, \%.

Because of the low pressure economizer for 1000 MW ultra super critical unit is not in simple series or parallel arrangement, the booster pump method has some energy saving effect, compared with the increasing condensate pump head method.

However, according to engineering experiences, the booster pump method is with more cost and engineering construction.

Therefore, only the increasing condensate pump head method is analyzed in this paper.

According to the economizer arrangement shown in Fig.1, the water intake could be divided into two parts: No.7 heater outlet and the water valve of shaft seal. 
The water from shaft seal valve could be deemed as parallel arrangement without increasing condensate pump output.

In addition, water from the No.7 heater outlet is in series model, so the condensate pump output increases to overcome economizer resistance. The power consumption result is shown in Table 4.

Table 4. The Power Consumption Increment of Condensate Pump and Draft Fan.

\begin{tabular}{lc}
\hline \multicolumn{1}{c}{ Items } & Data \\
\hline Pump efficiency $\eta_{\mathrm{p}} / \%$ & 84.5 \\
Water flow rate from No.7 heater outlet $/ \mathrm{m}^{3} \cdot \mathrm{h}^{-1}$ & 790 \\
Water flow rate from shaft seal valve $/ \mathrm{m}^{3} \cdot \mathrm{h}^{-1}$ & 336 \\
Main condensation water flow rate $/ \mathrm{m}^{3} \cdot \mathrm{h}^{-1}$ & 1875 \\
Water resistance of low pressure economizer $\Delta P_{\mathrm{w}} / \mathrm{Pa}$ & 612 \\
Power consumption increment $\Delta P_{\mathrm{p}} / \mathrm{kW}$ & 226.5 \\
Induced draft fan efficiency $\eta_{\mathrm{f}} / \%$ & 83.8 \\
Flue gas flow rate $q_{\mathrm{y}} / \mathrm{m}^{3} \cdot \mathrm{h}^{-1}$ & 4135663 \\
Gas resistance of low pressure economizer $\Delta P_{\mathrm{y}} / \mathrm{Pa}$ & 623 \\
Power consumption increment $\Delta P_{\mathrm{f}} / \mathrm{kW}$ & 854.1 \\
\hline
\end{tabular}

\subsection{Effect on flue gas system}

Low pressure economizer usually arranges between air preheater and electro precipitator, and it would increase the flue resistance. Hence, the draft fan output will increase to overcome flue gas resistance.

The power consumption of draft fan $\Delta P_{\mathrm{f}}$ is equal to $q_{\mathrm{y}} \cdot \Delta P_{\mathrm{y}} /\left(3600 \cdot \eta_{\mathrm{f}}\right)$. Where $q_{\mathrm{y}}$ is economizer gas flow rate, $\mathrm{m}^{3} / \mathrm{h}$. $\Delta P_{\mathrm{y}}$ is economizer gas resistance, $\mathrm{Pa} . \eta_{\mathrm{f}}$ is induced draft fan efficiency, \%.

As to the $1000 \mathrm{MW}$ ultra super critical unit, the power consumption increment result for draft fan is shown in Table 4.

In addition, the waste heat utilization has great effect on electro static precipitator performance. According to engineering experiences, the electro precipitator removal efficiency is greatly influenced by gas temperature.

The gas temperature reduction would decrease the flue gas viscosity, which could reduce the internal friction of particle movement and improve the drive speed of charged dust.

Besides, the gas temperature reduction would cause gas density and breakdown voltage increase. Hence, the dust collector efficiency is been improved.

According to the $1000 \mathrm{MW}$ unit investigated in this paper, after the waste heat utilization modification, because of the decrement of flue gas temperature and volume flow rate, the dust particle specific resistance reduces after $\mathrm{SO}_{3}$ absorption, which in turn greatly improves the electro precipitator removal efficiency.

\subsection{Effect on Desulfurization Process}

Waste heat utilization reduces the inlet gas temperature of desulfurization system, which causes the temperature decrement of desulfurization reaction and outlet gas.

Therefore, heat recycling will effectively reduce the water consumption of desulphurization system, in which the water consumption with 80 90 percentage concentrated in desulfurization tower.
In addition, the desulfurization reaction temperature decrement improves the dissolution and absorption of $\mathrm{SO}_{2}$ in limestone slurry with inhibiting the reaction rate. At the same time, the $\mathrm{SO}_{3}$ concentration in outlet flue gas is reduced because of soot particles absorption effect, which can sharply reduce the acid mist generation and PM2.5 emissions.

Besides, according to the 1000MW unit running experiences, the heat utilization modification did not improve desulfurization efficiency significantly.

\section{Annual economic analysis}

Combined with the heat utilization effect on steam turbine output and additional power consumption for draft fan with condensate pump, the comprehensive decrement for standard coal consumption rate $\Delta b_{\text {сp }}^{\prime}$ could be obtained as follows.

$$
\Delta b_{\text {ср }}^{\prime}=\Delta b_{\text {ср }}-\Delta P \cdot q /\left(P_{\mathrm{e}} \cdot 29.27\right)
$$

Where $\Delta P$ is auxiliary engine power consumption, $\mathrm{kW} . P_{\mathrm{e}}$ is unit power output, $\mathrm{kW}$. It is found that under turbine heat acceptance circumstances, the heat utilization could comprehensively reduce standard coal consumption rate by $1.89 \mathrm{~g} /(\mathrm{kW} \cdot \mathrm{h})$.

Moreover, the energy saving effect for economizer would change with the load variation, which is shown in Table 5.

It could be seen from Table 5 that along with the load decrement, the boiler efficiency increment rises and auxiliary engine power consumption decreases.

Table 5. Energy Saving Effect in Various Load Conditions.

\begin{tabular}{lccc}
\hline \multicolumn{1}{c}{ Items } & 100\%THA & 75\%THA & 50\%THA \\
\hline $\begin{array}{l}\text { Boiler efficiency increment } \\
\Delta \eta_{\mathrm{b}} / \%\end{array}$ & 0.63 & 0.70 & 0.78 \\
$\begin{array}{l}\text { Steam turbine power output } \\
\text { increment } \Delta P_{\mathrm{e}} / \mathrm{MW}\end{array}$ & 8.4 & 5.1 & 2.9 \\
$\begin{array}{l}\text { Auxiliary engine power } \\
\text { consumption increment / } \\
\text { MW }\end{array}$ & 1.08 & 0.56 & 0.34 \\
$\begin{array}{l}\text { Comprehensive standard coal } \\
\text { consumption rate decrement } \\
\Delta b_{\mathrm{cp}}^{\prime} / \mathrm{g} \cdot(\mathrm{kW} \cdot \mathrm{h})^{-1}\end{array}$ & 1.89 & 2.11 & 2.32 \\
\hline
\end{tabular}

Hence, the energy saving effect of heat utilization is more significant for lower load condition. The lower the load, the more the standard coal consumption decreases.

Based on the above investigation, the annual economic evaluation of the 1000MW unit could be calculated. Assuming that the unit runs 5200 hours a year, and the time proportion of the $100 \%, 75 \%$ and $50 \%$ load condition are $35 \%, 40 \%$ and $25 \%$ respectively.

Therefore, it can infer that the unit could save about 10.8 thousand tons standard coal and 1.29 billion dollars every year by means of waste heat utilization.

\section{Conclusions}

By means of equivalent enthalpy drop method, the flue gas waste heat utilization of a 1000 MW ultra super 
critical unit in Shandong Province is investigated, and its effect on boiler efficiency, steam turbine power output, condensate pump, induced draft fan, electro static precipitator and desulfurization system is analyzed.

It is found that under turbine heat acceptance circumstances, the heat utilization modification would decrease boiler exhaust temperature from $130{ }^{\circ} \mathrm{C}$ to $86.5^{\circ} \mathrm{C}$, and boiler efficiency rises from $93.5 \%$ to $95.8 \%$ with a $2.32 \mathrm{~g} /(\mathrm{kW} \cdot \mathrm{h})$ decrement for standard coal consumption rate.

In addition, waste heat utilization would cause power consumption increment for draft fan and condensate pump, precipitator efficiency improvement and desulfurization water consumption decrement. Under turbine heat acceptance circumstances, it could comprehensively reduce standard coal consumption rate by $1.89 \mathrm{~g} /(\mathrm{kW} \cdot \mathrm{h})$.

Finally, the investigation shows that by means of waste heat utilization, the unit could save about 10.8 thousand tons standard coal and 1.29 billion dollars every year, and the energy saving effect is more significant for lower load condition.

\section{References}

1. T. Bai, Z.P. Jin, Y.L. Wang, et al, "Study on the waste heat utilization system of 300 MW CFB boiler," Clean Coal Technology, 23 (2017)

2. G.V.P. Varma, T. Srinivas, "Power augmented steam power plant in a cogeneration cement factory," Journal of Energy Engineering, 143 (2017)

3. Y.F. Ma, L.J. Yang, J.F. Lu, et al, “Technoeconomic comparison of boiler cold-end flue gas heat recovery processes for efficient hard-coal-fired power generation,” International Journal of Energy Research, 41 (2017)

4. L. Pang, "Influence of a low pressure economizer on the thermal cost-effectiveness of its unit at a constant power output,” Journal of Engineering for Thermal Energy and Power, 31 (2016)

5. F.X. Yang, H.Z. Tan, J.J. Zhang, et al, “Comparison of different systems for waste heat recovery from flue gas in a 1000 MW power plant,” Clean Coal Technology, 23 (2017)

6. G.C. Liu, Y.F. Liao, X.Q. Ma, "Synthetical analysis of the heat recovery effects on coal-fired power units,” Boiler Technology, 48 (2017)

7. X.Y. Huang, F.Z. Sun, Y.T. Shi, "Energy saving effect of additional installed low-pressure economizer in thermal dynamic system of thermal power plant,” Thermal Power Generation, 03 (2008)

8. S. Park, J. Seo, "Analysis of air side economizers in terms of cooling energy performance in a data center considering exhaust air recirculation,” Energies, 11 (2018)

9. Y. Chen, Z.Q. Bao, “The thermal economy analysis of a 600 MW ultra-super critical unit with low pressure economizer by equivalent enthalpy drop method”, Energy Research an Utilization, vol.05, pp. 40-43, 2017.

10. J.X. Wang, W.P. Yan, D. He, “Energy conservation analysis for waste heat utilization system applying air preheater and using primary air to heat condensate water," Thermal Power Generation, 46 (2017)

11. T. Lv, Z.J. Zhang, S.J. Zhang, “Optimized choice for the connection mode of the water side of the low pressure economizer of a $600 \mathrm{MW}$ boiler,” Journal of Engineering for Thermal Energy and Power, 28 (2013)

12. L. Wu, “Analysis on transformation of low pressure economizer of 100 MW Unit boiler and its economical efficiency,” Guangdong Electric Power, 28 (2015)

13. D. He, W.P. Yan, J.Q. Xu, “Comprehensive optimization of inlet water temperature and temperature rise of low pressure economizer in utility boiler,” Boiler Technology, 46 (2015)

14. N.S. Ganesh, T. Srinivas, "Thermo dynamic assessment of heat source arrangements in Kalina power station,” Journal of Energy Engineering, 139 (2013)

15. B. Zhao, L.J. Zhao, P. Li, et al, "Thermal economic analysis on low-temperature waste heat recovery," Thermal Power Generation, 44 (2015) 